\title{
PHYSICAL REHABILITATION \\ OF THE MUSCULOSKELETAL SYSTEM FOR SCOLIOSIS
}

\author{
Sharun Sabina ${ }^{1}$ \\ Lisova Yelyzaveta ${ }^{2}$ \\ Scientific advisor: Straty Nataliya ${ }^{3}$
}

DOI: https://doi.org/10.30525/978-9934-571-89-3_83

The XXI century was marked by the century of new technologies, therefore in connection with the advent of the Internet, smartphones, computers and TVs, the modern population is devoting more and more time to gadgets and completely forget about their posture and overall health [1, p. 229, 231]. One of the most pressing problems in world practice is scoliosis, since this disease usually develops in people leading a sedentary lifestyle and those who are overweight, osteoporosis, osteochondrosis, etc. Approximately $80 \%$ of young people already have disorders of posture, which, in turn, lead to an increase in the risk of pathology not only of the locomotor system, but also of the main organs and systems (cardiovascular, digestive, respiratory, etc $[2, \mathrm{p} .10,12]$. Obviously, the need to apply broad medical and preventive measures to combat the posture disorders takes on social significance. The foregoing assumes the search for new means and forms, effective methods for correcting postural disorders and determined the relevance of the chosen topic.

The purpose of the study is the theoretical substantiation of the method of physical rehabilitation proposed for the correction of disorders of the musculoskeletal system in scoliosis.

The tasks of physical rehabilitation are the creation of favorable biomechanical conditions for optimal interposition of all body biosigns, directional correction of

\footnotetext{
${ }^{1}$ Kharkiv National Medical University, Ukraine

${ }^{2}$ Kharkiv National Medical University, Ukraine

${ }^{3}$ Kharkiv National Medical University, Ukraine 
existing disorders of the spine, pelvis, feet, the formation and consolidation of proper posture, and the creation of a muscular corset [3, p. 59].

The reason for the formation of scoliosis is the rapid growth of the spine with an underdeveloped muscle corset, the immaturity of the neuromuscular regulation, and hypodynamia. The fact is that the vertical body supports both the skeleton as a whole and a large array of muscles. Then the load is distributed evenly throughout the body. When a person sits down, the supporting muscular corset relaxes and the whole weight of the body passes to the spinal column. Great importance lies in the correct posture during eating and sleeping.

Most of the human movements (especially while working at the table, school desk) are associated with the predominant development of muscles that bend the torso. The muscles straightening the body, in the majority of movements a little involved. Inadequate exercise of these muscles affects the posture. The most common cause of acquired disorders of non-pathological posture is weakness of the trunk muscles, mainly the back and abdominal muscles, and the uneven distribution of "muscle traction" plays a decisive role [3, p. 59, 61, 62].

Early instrumental diagnostics allows for timely differentiated correction of disorders of the musculoskeletal system, which is extremely important. At the same time, complex treatment programs should be as individualized as possible. Therapeutic gymnastics should be aimed at correcting the existing disorders of the musculoskeletal system with the formation of a muscular corset and the creation of the skill of correct posture. Differentiated medical gymnastics is carried out depending on the type of static disorders - against the background of a pelvic bias in the frontal ("oblique" pelvis) and horizontal ("twisted" pelvis) planes [4, pp. 4-7].

Rehabilitation of patients with scoliosis, as most authors believe, is complex. The complex of conservative treatment of scoliosis includes medical gymnastics, massage, therapeutic swimming, orthopedic correction methods (corsetting, gypsum beds, etc.). electrostimulation, sparing motor mode, which provides load limitation on the spine. If necessary, prescribed traditional therapy, medication, diet [5, pp. 66-67].

Solving the problem of disorders of the musculoskeletal system is complicated by the lack of interest in physical culture among most people. Correction of violations of posture requires a specific, strictly regulated use of health-improving physical culture, taking into account the types and degree of spinal deformities. Unfortunately, the content of the correctional programs of university students is mainly of a generalized nature of the impact and does not solve the problems of specific violations of posture.

We have developed the following practical recommendations:

1. In the structure of the session, consistent training of long back muscles and abdominal muscles is necessary.

2. In increasing the static endurance of the muscles of the body is of great importance to the use of effective physical activity, taking into account the functional status of each student.

3. Formation of positive motivation of students assignments in physical education should be based on the interests of certain types of physical activity. 
4. When conducting classes in the SMG, it is recommended to pay attention to external signs of fatigue and monitor heart rate at the beginning, at the peak of the load and at the end of the lesson [6, pp. 3-5].

\section{References:}

1. Sultanova E.T., Shejko G.A. (2018). Vliyanie gadjetov na fizicheskyu formy [Influence of Gadgets on Physical form]. Proceedings of the Nauchno-prakticheskoj konferencii "Fizicheskaya kultura, sport i zdorove studencheskoj molodezhi v sovremennyx usloviyax: problemy i perspektivy razvitiya" (Russia, Yekaterinburg, 11 aprelya 2018) (eds. Olkhovskaya E.B.). Yekaterinburg: Rossijskij gosudarstvennyj professionalno-pedagogicheskij universitet, pp. 229-231.

2. Demeckaya A. (2018). Iskrivlenie pozvonochnika: pochemu voznikaet i kak lechat [Spinal curvature: why it occurs and how it is treated]. Pharmacist practices, vol. 9, no. 22, pp. 10-13.

3. Gajduk A.A., Potapchuk A.A. (2015). Fizicheskaya reabilitaciya detej mladshego shkolnogo vozrasta so staticheskimi narusheniyami oporno-dvigatelnogo apparata [Physical rehabilitation of children of younger school age with static disturbances of the support-motor apparatus]. Genius orthopedics, vol.1, no. 4, pp. 58-62.

4. Aleshkevich V.L., Ogorodnikov S.S., Azarova E.A. (2018). Puti sovershenstvovaniya raboty po fizicheskomu vospitaniyu v vuze [Ways to improve work on physical education in the university]. Proceedings of the III mezhdunarodnoj nauchno-prakticheskoj konferencii (Belarus, Minsk, April 12-13) (eds. E.S. Wanda). Belorusskij gosudarstvennyj medicinskij universitet, pp. 4-7.

5. Pokatilov A.B., Novak A.P., Xvorostova A.V. (2017). Profilaktika narusheniya osanki u detej [Prevention of breaks in children]. Head Doctor of the South of Russia, vol. 3, no. 56, pp. 66-68.

6.Anikeeva V.V., Fomenko E.G., Bochkarnikova N.V. (2014). Ozdorovitelnye texnologii v specialnyx medicinskix gruppax u studentov s narusheniyami osanki [Health technologies in special medical groups of students with body disorders]. Bulletin of the Buryat State University. Pedagogy. Philology. Philosophy, vol. 6, no. 12, pp. 3-5. 